WORKING PAPER 258

\title{
Gender and forest tenure reform in Indonesia
}

Mia Siscawati
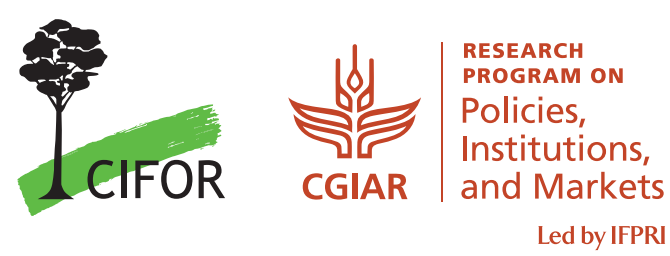

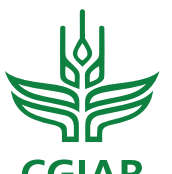

CGIAR 

Working Paper 258

\section{Gender and forest tenure reform in Indonesia}

Mia Siscawati

Graduate Program on Gender Studies, School of Strategic and Global Studies, University of Indonesia 
Working Paper 258

(C) 2020 Center for International Forestry Research

(c) (i) Content in this publication is licensed under a Creative Commons Attribution 4.0 International (CC BY 4.0), http://creativecommons.org/licenses/by/4.0/

DOI: 10.17528/cifor/007572

Siscawati M. 2020. Gender and forest tenure reform in Indonesia. Working Paper 258. Bogor, Indonesia: CIFOR.

\section{CIFOR}

Jl. CIFOR, Situ Gede

Bogor Barat 16115

Indonesia

$\mathrm{T}+62(251) 8622-622$

F +62 (251) 8622-100

E cifor@cgiar.org

\section{cifor.org}

We would like to thank all funding partners who supported this research through their contributions to the CGIAR Fund. For a full list of CGIAR Fund Donors please see: http://www.cgiar.org/about-us/our-funders/

Any views expressed in this publication are those of the authors. They do not necessarily represent the views of CIFOR, the editors, the authors' institutions, the financial sponsors or the reviewers. 


\section{Contents}

Acknowledgments $\quad$ iv

Summary $\quad$ v

1 Introduction 1

2 Forest tenure reform in Indonesia 3

3 Conceptual framework for examining gender and forest tenure reform in Indonesia 4

4 Macro scale of gender and forest tenure reform 6

5 Meso scale of gender and forest tenure reform: National, provincial and district levels 7

$\begin{array}{lll}5.1 & \text { National level } & 7\end{array}$

5.2 Provincial and district levels $\quad 8$

6 Micro scale of gender and forest tenure reform $\quad 11$

6.1 Gendered daily economic roles of community-managed forest 11

6.2 Gendered demographic issues, forest tenure reform and the status of forest resources 11

6.3 Domestic roles and involvement in forest management 11

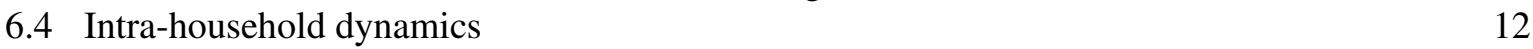

$\begin{array}{ll}\text { 6.5 Gendered benefits and economic strategies } & 13\end{array}$

7 Conclusion $\quad 14$

$\begin{array}{ll}\text { References } & 15\end{array}$

\section{List of table}

\section{Table}

1 Framework for analyzing gender and forest tenure reform adapted from the 'gender box' developed by Colfer (2013) 


\section{Acknowledgments}

CIFOR's 'Global Comparative Study on Forest Tenure Reform' is funded by the European Commission and the Global Environmental Facility (GEF) with technical support from the International Fund for Agricultural Development (IFAD) and the United Nations Organization for Food and Agriculture (FAO). We would like to thank FAO for helpful reviews and comments on an earlier version. This study forms part of the Program on Policies, Institutions and Markets (PIM), led by the International Food Policy Research Institute (IFPRI); and the CGIAR Research Program on Forest, Trees and Agroforestry (FTA), led by CIFOR. This report has not gone through standard peer-review procedures. The opinions expressed here represent the analysis of the authors and do not necessarily reflect the views of IFPRI, CIFOR, CGIAR or the financial sponsors. 


\section{Summary}

This report considers the gender dimensions of forest tenure and forest tenure reform in Indonesia. Data were derived from CIFOR's research on forest tenure reform in Indonesia at the national and provincial levels, focusing on the provinces of Lampung and Maluku. Additional data were taken from training workshops on gender and community-based forest tenure reform held at these two sites.

The study shows that, at the macro scale, the gender dimension of forest tenure reform is marked by the intersection of global efforts toward gender equality and women's empowerment with the development of equitable and sustainable forest resources through forest tenure reform.

At the national level, policies on gender equality and women's empowerment have contributed to the development of gender mainstreaming policies within the forestry sector. However, national forest tenure reform policies and programs still give little consideration to gender equality and women's empowerment.

The meso scale of provincial and district levels is marked by the implementation of gender-neutral national forest tenure reform policies and programs at landscape level.

In Lampung Province, two permits within social forestry schemes, namely hutan kemasyarakatan (HKm or community-managed forests) and hutan tanaman rakyat (HTR, community-based plantation forests), predominate. In contrast, hutan adat (customary forest) is more commonly found in Maluku Province. Local communities in Maluku Province are currently searching for a forest tenure reform scheme that best protects their tenurial rights to forest lands and resources.

At the micro scale, the case study of Lampung Province shows that the implementation of forest tenure reform schemes has not significantly changed gender norms. Nevertheless, women's participation in decision making at household and community level is gradually increasing, albeit in a limited way. Since the implementation of $\mathrm{HKm}$ permits, household income from secured forest lands has increased. This rise in income is slowly increasing the likelihood that girls will have higher education.

The application of forest tenure scheme(s) at micro scale in Lampung has made women feel safe and secure in managing the land, without fear of intervention by authorities. They are able to manage non-timber forest products and earn cash income to cover living expenses. They also contribute to sustainable forest management, replanting to preserve plants from extinction.

In addition, security of tenure rights appears to have led to a decrease in the number of men temporarily migrating in order to look for work or additional cash income. The presence of more adult men in the family has positively contributed to the utilization of the forest land under HKm permits, which has had a positive impact on the land and resources.

The case study of Maluku Province shows that the existing tradition of active participation of women in household and community decision making could contribute to the recognition and protection of their rights, and those of other marginal groups, over forest lands and resources. 



\section{Introduction}

Tenure is a generic term linked to a variety of arrangements that regulate access to and use of certain resources. According to FAO (2006), tenure arrangements may involve "exclusive access (when only one person or group has access), or different types of access for different groups of people at different times." Land tenure issues have been examined and debated for many years: Henry Maine referred to it in works such as Ancient Law (1861) and Village Communities in the East and West (1871). Elinor Ostrom explored the concept of resource tenure through field studies on how people in small communities manage shared natural resources, such as pastures, fishing waters and forests. Her works, particularly Governing the Commons (1990) and 'Private and common property rights' (1999), have contributed to our understanding of resource tenure.

Forest tenure refers to ownership, tenancy and other arrangements for the use of the forest. It determines "who is allowed to use which resources, in what way, for how long and under what conditions, as well as who is entitled to transfer rights to others and how. Different rights may be shared or divided in a number of ways and among stakeholders, as are obligations and responsibilities associated with rights" (Larson 2012). This is closely linked with the concept of tenure rights to natural resources, which refer to the social relations and institutions governing access to and use of land and resources (von Benda Beckman et al. 2006). Resource tenure scholars have highlighted that, in some cases, trees could become subject to multiple tenure rights (Fortmann 1985; Fortmann and Bruce 1988).

Exploration of the dynamics of forest tenure and forest governance in Indonesia has focused mostly on contested processes between the State and forest-dwelling communities, particularly Indigenous Peoples, customary communities and other local communities. Many studies view 'community' as a homogenous entity and little consideration has been given to the way gender, class, ethnicity, religion and other socio-cultural aspects provide critical contributions to the formation of sub-groups within a 'People', as well as multiple identities of the members of each sub-group. Therefore, gender-based injustices in forest tenure and forest governance, as experienced mostly by women, have not been adequately addressed (Siscawati and Mahaningtyas 2012; Marcoes et al. 2015).

In Indonesia, most of the policy advocacy work on forest tenure and governance reform organized by civil society organizations has focused on how to resolve the conflict between customary forest tenure systems and the 'political forests' under state control (with their associated system of territorialization, zoning and management) and established under law. While this advocacy work seeks to change both the legal framework and its implementation, as well as address systems of conflict resolution, all too often the question of gender inequalities is neglected (Siscawati and Mahaningtyas 2012; Marcoes et al. 2015). As a consequence, forest-related policies and community-based forest resource management programs have done little to adopt a gender equality perspective. The gender dimensions of forestrelated conflicts are, however, discussed in the 'Special Report of the Results of the 2016 National Inquiry on the rights of Indigenous Peoples over customary territories located in the forest zone' ${ }^{1}$ (KOMNASHAM 2016).

This brief explores the gender dimension of forest tenure and forest tenure reform in Indonesia, resulting from CIFOR's research on forest tenure reform in Indonesia (Herawati et al 2017; Liswanti

1 The need for a gender perspective was highlighted in the decision of the People's Consultative Assembly, the police regulation, Ministry of Agriculture, Ministry of Law and Human Rights, not only in handling natural resources disputes and conflicts but also to increase capacity of indigenous people. 
et al 2017). The aim was to analyze the effect of different tenure reform types on the management and use of the forest by local communities and other actors. Research was conducted at the national, provincial and local levels, focusing on the provinces of Lampung and Maluku. ${ }^{2}$

Applying a mixed-method approach, the research combined different tools of quantitative and qualitative data collection. At the national level, legal and historical analysis of key regulations around reforms illustrated how reforms emerged. At the local level, semi-structured interviews, intra-household surveys and focus groups generated information and promoted the participation of local stakeholders in the discussion of the origins and nature of forest tenure reform outcomes. Data collection at the local level in Indonesia was carried out in 16 villages located in two provinces (Lampung and Maluku) in which forest resources are managed under different tenure regimes. Results for women, men, youth and adults were grouped separately to elicit the actual and perceived impacts of forest tenure reforms. Additional data for this brief is taken from training workshops on gender and community-based forest tenure reform held in both provinces.

2 More information can be found on the project website: https://www.cifor.org/gcs-tenure/ 


\section{Forest tenure reform in Indonesia}

Indonesia began reforming forest tenure in the mid-1980s through dynamic, interactive, collaborative processes. Both state and non-state actors actively participated in these processes. Until the mid-1990s, forest tenure reforms in Indonesia were marked by the gradual involvement of local communities in the state-sponsored social forestry programs. Social forestry was not yet considered important, as timber-based forestry still dominated the way the government managed forest resources. Customary forest was also not legally recognized by the Basic Forestry Law No. 5 of 1967. The revision of this law into Forestry Law No. 41 of 1999 marked important changes. The revised law officially mentions customary forest (hutan adat). However, it still includes customary forest as state forest under the control of customary community (masyarakat adat). The law does not mention social forestry schemes in its main text, but two of the schemes, namely HKm (community-managed forest) and hutan desa (village forest), are mentioned briefly in the explanation part of the law. Nevertheless, the 1999 Forestry Law has served as a legal basis for the further development of social forestry schemes.

Since the establishment of the 1999 Law, the discourse of social forestry has been incorporated into regulations and programs. However, social forestry schemes have not been effectively implemented in Indonesia for the following reasons: (a) the onerous process of obtaining a permit; (b) a lack of direction and motivation of staff within implementing agencies to effect social forestry; (c) limited capacity and resources of both communities and implementing agencies to comply with the technical requirements to process permits; and (d) macro-level economic prioritization of extractive activities that concentrate benefits in the corporate sector. Moreover, both the design and the implementation the social forestry schemes in Indonesia have not adopted a gender perspective. Women of various social groups and marginal members within communities have been largely left out (Siscawati et al. 2017).

Apart from the development of the social forestry schemes, key actors of the Indigenous Peoples movement in Indonesia represented by the Alliance of Indigenous Peoples of the Archipelago (AMAN) submitted a judicial review of the 1999 Forestry Law to the Constitutional Court in November 2012, heard as Case No. 35/2012. The main substance of the review was that some articles of the law violate the constitutional rights of Indigenous Peoples. In May 2013, the court ruled that land and forests within customary territories was no longer state land and forests. Moreover, the ruling made Indigenous Peoples the legal subject and rights bearers of customary lands and resources (Rachman and Siscawati 2014, 2016). The result of this judicial review was considered a victory for Indigenous Peoples by AMAN and its members. Nevertheless, rural indigenous women have had limited representation and involvement in the struggles of adat communities in reclaiming their rights, including the rights over customary land and territories. In a period when Constitutional Court Ruling No. 35/PUU-X/2012 is referred to as a state policy that recognizes adat communities as right bearers, and as legal subjects of customary territory, adat women still do not receive full recognition from their own communities, social movements or the state (Siscawati 2014).

The Constitutional Court Decision was followed by at least four major implementation regulations: (a) Ministerial Regulation No. P.62/Menhut-II/2013 on the Changes of Ministerial Regulation No. P.44/Menhut-II/2012 on the Gazettment of Forest Areas, which recognizes customary communities; (b) Ministerial Regulation No. 10/2016 on Procedures and Modalities on Communal Land Rights by Indigenous Communities and Other Communities inside Specific Areas (ATR/BPN), which contains the substance of reviving communal/collective rights; (c) Ministerial Regulation No. P.32/MenlhkSetjen/2015 on Forest Rights (KLHK), which contains the substance of reviving customary forest; and (d) Ministerial Regulation No. P.83/Menlhk/Setjen/Kum.1/10/2016 on Social Forestry, which contains the substance of inclusion of adat forest into the social forestry scheme. 


\section{Conceptual framework for examining gender and forest tenure reform in Indonesia}

In examining gender, forest tenure and forest tenure reform at CIFOR's project sites in Lampung and Maluku, I apply Carol Colfer's conceptual approach, 'the gender box', which is a framework for analyzing gender roles in forest management. Colfer (2013) states that the framework aims "to examine and consider which of these forces—whether formal or informal-are affecting men and women in the areas where we work." The framework for analyzing gender roles in forest management examines issues at three different scales, macro, meso and micro, that affect how women and men use and manage forest resources and receive benefits (Colfer 2013).

The macro scale of this framework refers to broad, global 'rules' that affect people's interactions with forests. It includes policy and laws as well as less formal, but powerful, cultural, religious and 'modern' notions. The meso scale of the framework links to social patterns from landscape to national levels that influence people's behavior in relation to forests. The meso scale is "the most geographically diverse, ranging from formal administrative units (the state and below), to the supra community area inhabited by a particular ethnic, caste/class or religious group." At this scale, significant issues addressed include (a) land tenure and access to resources/assets; (b) norms about gender and age; (c) educational opportunities; and (d) changes from subsistence to cash economies. The micro scale refers to human behavior from household to village levels that affect forests and people's wellbeing. At the micro level, the literature highlights five broad clusters of issues: (a) economic roles; (b) local demographics; (c) domestic roles; (d) intra-household power dynamics; and (e) alternative paths for life-changing improvements (Colfer 2013).

To examine gender and forest tenure reform in Indonesia, I slightly modified Colfer's conceptual approach to develop a framework for analysis. In doing so, I considered the intersection of forest tenure reform and gender dimensions and dynamics at all three scales.

Table 1. Framework for analyzing gender and forest tenure reform adapted from the 'gender box' developed by Colfer (2013)

I. Macro scale: Broad-based, global 'rules' related to forest tenure reform that affect people's interactions with forests

A. Are there formal global laws and policies on forest tenure reform that affect local people and forests? How?

B. What religious traditions, narratives of modernity or equity, or other less formal, global intellectual forces, linked to forest tenure reform, affect local people and forests?

II. Meso scale: Social patterns related to forest tenure reform from landscape to national levels that influence people's gendered behavior in relation to forests

A. How is the gender dimension adopted in national, provincial and district level on forest tenure reform policies and programs? How is gendered access to resources in the forest tenure reform scheme implemented? 
Table 1. Continued

B. How do forest tenure reform policies, programs and schemes affect gendered norms of people's behavior in terms of their interactions with trees and forests (e.g. masculinity ideals, limited involvement of women, etc.)?

C. How do forest tenure reform policies, programs and schemes contribute to gendered differences in access to education (both formal and informal) through increasing household income? How do they affect men, women and forest management differently?

D. How important are forest tenure reform policies, programs and schemes in contributing cash to the regional system, and how has this affected men and women differently?

\section{Micro scale: Human behavior from household to village levels that are in line with forest tenure reform which affect forests and people's well being}

A. How do the day-to-day economic roles of men and women differ-especially in terms of agriculture, forest products and livestock?

B. What gendered demographic issues affect forests and people locally (e.g. migration, population changes, access to birth control)?

C. What essential/valued domestic roles do men and women play, respectively (e.g. cooking, hygiene, child and elder care, health, fuel-wood collection) that affect their involvement in forests?

D. What patterns are identifiable in intra-household power dynamics within the context of the implementation of forest tenure reform at village level? In what ways do the interests of men and women conflict or converge? Are there bargaining strategies used by each?

E. What features (e.g. collective action, access to technology, distribution of benefits, time constraints/ conflicts) of locally available, alternative economic strategies are designed to enhance people's livelihoods, trees and forests within the context of the implementation of forest tenure reform at village level? How do these differentially affect men and women? 


\section{Macro scale of gender and forest tenure reform}

At the macro scale, the gender dimension of forest tenure reform is marked by the intersection of global efforts toward gender equality and women's empowerment and toward just and sustainable forest resources through forest tenure reform.

According to the Report of Rights and Resources Initiative (RRI) on women's rights to community forests (RRI 2017), "equal rights and opportunities for women are not only matters of justice and dignity." RRI continues, "When women and girls have equal rights in law and practice, their communities and countries also benefit. Indigenous and rural women make up more than half of the 2.5 billion people who customarily own and use the world's community lands, yet they have been largely absent from discussions of women's property rights and broader development agendas" (RRI 2017).

An influential convention on women's rights is the International Convention on the Elimination of All Forms of Discrimination Against Women (CEDAW). Proponents of gender equality and women's empowerment within forest governance have referred to this convention in the development of international policies on forest governance that include a gender equality and women's empowerment perspective. However, because CEDAW contains no reference to Indigenous women, the substance of CEDAW must be interpreted together with the United Nations Declaration on the Rights of Indigenous Peoples.

Another relevant international policy is Goal 5 of the Sustainable Development Goals (SDGs), which aims to "achieve gender equity and empower all women and girls." This goal includes equal rights to economic resources, ownership and control of land and other resources, and other aspects that directly challenge current relations of power through women's access to and control over assets (Bose et al. 2017). In other words, it aims to address structural and material dimensions of gender disparities. Moreover, the targets of the goal include full and effective participation for women and equal opportunities for leadership in multiple spheres. It also targets structural and cultural changes to support greater participation of women outside the household (Bose et al. 2017).

Goal 5 plays a significant role in the recognition and protection of women's rights to communal forests, agrarian land and resources in rural and indigenous territories. In Indonesia, Goal 5, among others that have gender dimensions, is being considered in the formulation of national and subnational policies and programs on development of natural resources, including those on forest lands and resources.

Lastly, the internationally endorsed Voluntary Guidelines on the Responsible Governance of Tenure (VGGT) provisions are also relevant here. VGGT calls for "Ensuring equal rights of women and men to enjoyment of all human rights, while acknowledging differences between them and taking specific measures aimed at accelerating equality [and] ensuring that women and girls have equal tenure rights and access to land, fisheries and forests independent of their civil and marital status" (FAO 2012). 


\section{Meso scale of gender and forest tenure reform: National, provincial and district levels}

\subsection{National level}

The gender dimension of forest tenure reform at the national level in Indonesia is marked by legal and policy frameworks for gender equality and women's empowerment and by the gender dimension of policies and programs on forest tenure reform.

\subsubsection{Legal and policy frameworks for gender equality and women's empowerment in Indonesia}

The 1945 Constitution of the Republic of Indonesia states, "all citizens have equal status before the law" (Article 27). Although it does not specifically distinguish between female and male citizens, it is one of the basic legal foundations for women's rights in Indonesia. In 2017, RRI published a report assessing 80 legal frameworks regulating indigenous and rural women's community forest rights in 30 developing countries. This covered 78 percent of the developing world's forests. The report highlighted that Indonesia is one of only two countries assessed that does not guarantee women equal protection under the constitution.

Indonesia has signed CEDAW, ratifying it in 1984. This means that Indonesia should implement Article 14 of CEDAW, which states that "State Parties shall take all appropriate measures to eliminate discrimination against women in rural areas [and] shall ensure to such women the right [...] to have access to $[\ldots]$ and equal treatment in land and agrarian reform as well as in land resettlement schemes."

A new approach to state policies in all sectors based on gender equality was introduced in the 1999 Guidelines on State Policy (GBHN). This states that women are empowered by improving their role and status in national life through national policy implemented by institutions that work to achieve gender equality and justice. Under the leadership of President Abdurrahman Wahid, there was a significant move toward gender equality and women's empowerment. A major outcome of his leadership was the National Plan of Action to Empower Women, running from 2000 to 2004. Presidential Instruction No. 9/2000 was enacted, stating that all ministries and all government agencies, including district and provincial offices, were to conduct gender mainstreaming by enacting ministerial and government regulations that consider gender equality and women's empowerment. This Decree was followed by gender-awareness and capacity-building programs for top officials in ministries and all government agencies.

The 1999 Presidential Instruction also applies at the subnational level (provincial and district levels). Under the guidance of the Ministry of Home Affairs, government agencies down to the district level are obliged to mainstream gender in regional development plans. The Ministry of Women's Empowerment and Child Protection is the government agency in charge to provide technical assistance to other ministries on gender mainstreaming.

The process of gender mainstreaming, however, did not gain momentum until the introduction of Gender Responsive Budgeting (GRB). GRB was officially introduced through the Minister of Finance Regulation of 2009, followed by its incorporation into the budgeting system in seven pilot ministries. 
These seven ministries include four technical ministries (Ministries of Agriculture, Education, Health and Infrastructure), and three coordinating ministries (Ministries of Finance, Women's Empowerment and Child Protection, and the National Planning Agency). As a next step, other ministries and other state agencies are requested to submit Gender Budget Statements as an appendix to their annual work plan budget. These statements outline the gender inequalities or gaps to be addressed in their programs and activities, in accordance with the strategic planning document. The 2009 Regulation was followed by the Minister of Finance Regulation of 2012 on the Guidelines for the Preparation and Review of the Work Plan and Budget of State Ministries/Institutions, which also included the integration of gender in state ministries' budgets.

Presidential Regulation No. 2 of 2015 on the National Medium-Term Development Plan 2015-2019 stipulates that gender mainstreaming is one of the "Cross Cutting Issues" in national development. This regulation has also been used to establish performance indicators of each ministry, national state agency and local government for mainstreaming gender in development policies and programs at national, provincial, district and city levels.

\subsubsection{Gender mainstreaming in forest-related policies}

Forest-related policies that were enacted prior to the year 2000 did not adopt gender equality principles. Specifically, Basic Forestry Law No. 5 of 1967, which was revised as Forestry Law No. 41 of 1999, did not consider the gender dimension of forest tenure and management of forest resources.

Gender mainstreaming in the forestry sector began a few years after the issuance of the Presidential Instruction on Gender Mainstreaming in 2000. It began with the Decree of the Minister of Forestry No. 528 in 2004 on the implementation of the guidance of gender mainstreaming in the development of forestry sector. The ministry then issued Ministerial Regulation P. 65/2011 dated October 11, 2011, on guidelines for gender-responsive planning and budgeting in the forestry sector as a follow up of the Decree of the Minister of Forestry No. 528 of 2004. This ministerial regulation emphasized that the development of the forestry sector in realizing national development should be "pro-poor, pro-jobs, and pro-environment." This approach has a strong gender dimension that needs to be addressed with further gender-related actions.

Both the Ministerial Decree No. 528/2004 and Ministerial Regulation P.65/2011 were revised in 2017 by the Ministerial Regulation P.31/2017 on the guidance of the implementation of gender mainstreaming in the environment and forestry sector.

\subsection{Provincial and district levels}

The gender dimension of forest tenure reform at the provincial level in Indonesia is marked by its implications for gender norms and women's participation, its contribution to gendered access to education, and its contribution to the importance of cash income and gendered management of income.

\subsubsection{How forest tenure reform policies, programs and schemes affect gender norms and women's participation}

Local communities in CIFOR's research sites in Lampung and Maluku show certain similarities in gender norms. Women have a greater role in domestic/reproductive work. Where women also participate in livelihood strategies, gender roles are relatively balanced. Roles are also relatively balanced in social activities, where women participate in communal rituals and other community-level activities. Many women of all communities at the research sites participate in different organizations. These include the state-supported women's organization (PKK), women's religious groups and women farmers' groups. 
In Lampung, however, women play less of a role in activities designed by village government or upper-level administrations (sub-district, district, and provincial governments). Moreover, women participate less than men in other decision-making process at community level. This is because community-level decision making forms part of village government or external institution meetings, which are held at times that women cannot attend due to their domestic duties. In many cases, the community-level decision-making process took place in evening meetings when socio-cultural norms prevent women from leaving their homes. Nevertheless, women in Lampung relatively actively participate in decision making at the household level.

In the case of Lampung Province, local gender norms mean men dominate the application process for HKm and HTR permits, two of several schemes for forest tenure reform implemented in this province. After the local communities formally received HKm and HTR permits, there was no significant change in gender norms. Women's participation in decision making at community level, particularly at the organizational level (within the HKm group) is still limited. Nevertheless, in areas where women have significant roles in taking care of products, such as coffee beans, harvested from HKm lands, women's participation at community level has gradually increased. Many women who are active in caring for coffee trees planted in HKm areas have joined several meetings organized by the HKm group. However, attendance at these meetings is still limited to key members of a group of female coffee farmers. This group is focused on marketing the coffee beans of its members.

In the case of Maluku Province, women are relatively more active in decision making at both household and community levels. As in Lampung, however, when it comes to the decision making conducted during formal meetings held by village government or upper-level administrations women's participation is relatively low. This is due to the time of the meetings (mostly in the evening), distance to the meeting locations and women's domestic roles.

Considering that communities in Maluku Province are still searching for the best forest tenure reform scheme, women's active participation in decision making at both household and community levels could be strategically utilized. Their voice should be heard in adat and local community discussions.

\subsubsection{How forest tenure reform policies, programs, and schemes contribute to gendered differences in access to education (both formal and informal)}

Information gathered during a training program on gender and forest tenure reform organized by CIFOR in both provinces in late 2017 revealed gendered access to formal education at the micro scale has been slowly increasing since the implementation of forest tenure reform schemes. This appears to relate to security of status of the land within the HKm scheme, which contributes to income security from land-based resources, including coffee beans, resulting in a gradual increase in women's overall level of education.

Moreover, female participants in CIFOR's training program in Lampung stated that after the issuance of the HKm permit the number of child marriages had decreased. These women stated that child marriage practices in the past were mostly influenced by a combination of socio-cultural norms, household economy and the education level of the girls. They explained that increased income from forest lands that were secured through the permit, and the increased education levels for girls (also influenced by the security of income from land-based resources) contributed to a reduction in child marriages.

Nevertheless, girls of certain social groups still face problems in terms of access to education. Families with limited income and capital required to manage productive lands still struggle to pay school fees. Girls from these families receive less parental support, as their parents need to spend more time working. They also lack understanding of the purpose of education. This means they have low interest in school and may even drop out. 
After the local communities in Lampung received their formal permit, men of particular social groups, such as formal and informal leaders, who previously had access to informal education (mostly organized by non-governmental organizations) gained further access to this informal education. These men have received more opportunities to join training schemes on forest management and forest product utilization.

Women farmers involved in processing products from forest lands and resources that had been officially secured through forest tenure reform schemes have also gained increased access to informal education, including technical training on forest and agricultural products. Nevertheless, many other women farmers are reluctant to join. They feel that they are too old, and that their current capacities in managing their lands are sufficient. In addition, their time is limited due to domestic roles and the distance of training venue from their houses.

In Maluku Province, local community access to formal and informal education is relatively equal between men and women.

\subsubsection{How forest tenure reform policies, programs, and schemes contribute to the importance of cash income in the regional system and gendered management of income}

In Lampung, the implementation of forest tenure reform schemes has contributed to both secure and increase cash income. This is from the sale of products from forest lands under HKm permits, especially coffee beans. However, there is still inequality among households that manage forest lands under HKm or HTR permits. Some members of HKm group have produced forest and agricultural products that have high economic value. Others still have financial issues due to crop failure, very limited livelihood strategies, too many family dependents and limited time (mostly for women) due to heavy domestic roles.

In Maluku, forest lands and resources managed by local communities using customary systems not only provide for subsistence but also contribute to cash income. Once their forest tenure rights are secured through a suitable forest tenure reform scheme, the local communities hope that their cash income will increase.

Many families in Lampung and Maluku have developed gendered management of cash. Men generally sell the products from forest lands and give a portion of the cash to their wives for domestic needs. Many wives, however, never write down the household needs and detailed expenditures and most husbands never ask whether the money given each month is sufficient for everyday needs. Participants found discussions on cash management at household level particularly useful during CIFOR's training sessions on gender and forest tenure reform because: (a) they gave the male participants an idea of the complexity of managing household finances, usually handled by the wife or other female member of the household; (b) they showed male participants women's struggles to meet the daily needs during difficult times (crop failure due to drought, etc.); and (c) they encouraged participants to think about increasing productivity of their $\mathrm{HKm}$ lands in innovative and sustainable ways. 


\section{Micro scale of gender and forest tenure reform}

\subsection{Gendered daily economic roles of community-managed forest}

The main question of this section refers to how the day-to-day economic roles of men and women differ-especially in terms of agriculture, forest products and livestock.

Women's daily work on productive lands linked to their economic roles, includes: (a) working in the rice fields (planting, spraying fertilizers and harvesting); (b) working in the garden (clearing the lands, weeding, removing shoots and unproductive branches, fertilizing, etc.); (c) harvesting coffee beans; (d) collectively processing coffee beans, cassava, palm sugar, banana, rice, sticky rice and handicrafts for souvenirs (these activities are usually conducted by the women farmers' group); and (e) taking care of the group stall, while packaging and marketing the products.

Men's work on productive lands linked to their economic roles, includes: (a) working in the garden (spraying chemicals to clear the land from grass and other weeds, taking care of the nursery, growing vegetables and other cash crops, and harvesting produce); (b) working in the rice fields (plowing, cultivating, harvesting, growing rice); (c) taking care of the animals (making and taking care of cages, and grazing and nurturing the animals).

\subsection{Gendered demographic issues, forest tenure reform and the status of forest resources}

Local communities in Lampung mentioned that the security of tenure rights of forest lands from their permits has contributed to a decrease in men's temporary migration for work or additional cash income. The presence of more adult men in the family has positively contributed to the utilization of the forest lands that the state allows to be managed (through forest tenure reform scheme(s)), which has had positive impacts for forest lands and resources. In addition, the presence of men has also positively contributed to better management of lands owned by the family (such as rice fields). Moreover, local women who participated in CIFOR's training on gender and community-based forest tenure reform stated that the presence of their husbands and adult male members of their family has allowed the women to share productive roles.

\subsection{Domestic roles and involvement in forest management}

The main question in this section on the micro scale of gender and forest tenure reform refers to what essential/valued domestic roles men and women play, respectively (e.g. cooking, hygiene, child and elder care, health, fuel-wood collection) that affect their respective involvement in forests.

In Lampung, participants of CIFOR's training program on gender and community-based forest tenure reform shared that women's domestic roles include cooking, child care, taking care of their husbands (preparing their meals and clothes), sweeping and mopping floors, cleaning the house, cleaning the yard, washing and ironing clothes, and grocery shopping. Many women are helped by their daughters who are usually responsible for sweeping and mopping the floors, taking care of the yard, washing crockery and clothes, as well as ironing and cooking. 
In addition to conducting domestic roles, the women in Lampung have social roles: attending weekly and monthly Quran recitation; attending activities organized by PKK, Posbindu (Elderly Posyandu); visiting the sick; and helping neighbors who are organizing weddings or other ceremonies.

Men's domestic roles are quite limited; only two activities, cleaning the house and washing their own clothes, were listed. The men are usually helped by their sons who participate in cleaning the house and watering plants in the yards.

Men's social roles include attending farmers' group activities, collective social work (gotong royong), participating in community-based monitoring of the village (siskamling) and attending formal meetings organized by village government.

The training participants identified that women and girls play a more dominant role in domestic duties, while also performing productive and social duties. In addition, women work longer during the day than men. Women have to get up early to prepare food, wash and clean the house. Girls also have to help their mothers.

Women's long list of domestic and social roles contributes to their limited productive role. In addition, women also have limited time to participate in other activities related to forest management, such as attending technical training and decision-making meetings.

The implementation of forest tenure reform schemes has not changed women's domestic and social roles. This relates to the previous discussion on gender norms in which forest tenure reform at micro scale has not contributed to any changes on gender norms. Nevertheless, the increase in girls' education, along with increasing income, after the issuance of the HKm permit, could contribute to changing gender norms in the future and would allow more women to actively participate in activities related to forest management.

\subsection{Intra-household dynamics}

The main question for this section refers to patterns in intra-household power dynamics within the context of the implementation of forest tenure reform at village level. Secondary questions refer to what ways the interests of men and women conflict or converge, and whether each uses bargaining strategies.

For the case of Lampung, the intra-household dynamics within the context of forest tenure reform at village level are shown by the dynamics of relationships among household members of the forest farmers' groups (the HKm group and the HTR group) and women farmers' groups, whose main work is processing forest and agricultural products and marketing these products. Gender-based power relations enrich the relationships among members of these groups. They admitted that there is also conflict. In responding to this problem, traditional ways of resolving conflicts among individuals are applied, for example by involving prominent elder individuals (mostly men) to serve as conflict mediators. However, the groups have been trying to build mechanisms to address conflict among group members.

The implementation of forest tenure reform in Lampung, through HKm and HTR permits, has contributed in limited ways to positive changes in intra-household dynamics. The training sessions organized either by civil society organizations or government agencies, which aimed to strengthen farmers' capacities, have allowed the villagers to further develop their relationships in productive work on forest lands. Village-level meetings, facilitated by these institutions to prepare technical plans for forest management, have also contributed to more positive interactions among villagers. 


\subsection{Gendered benefits and economic strategies}

The application of forest tenure scheme(s) at micro scale in Lampung has the following benefits for women: (a) they feel safe and secure in managing the land because they have a license; (b) they are not afraid of being challenged by the authorities; (c) they can manage non-timber forest products and earn cash income that can be used to cover living expenses; and (d) they can preserve nature and the environment.

Men benefit in the following ways: (a) they have security in managing the land; (b) they do not need to leave the village to look for work; (c) they can develop alternative livelihood strategies; (d) they can manage the permitted area; (e) they can utilize forest products; (f) they have more understanding of social forestry schemes; and $(\mathrm{g})$ they better understand the rules within the forestry sector.

Benefits of the application of forest tenure reform scheme(s) for the family are: (a) secure land for cultivation; (b) increased family income; (c) a healthy environment with clean air; (d) good harvests from the land; (e) improved assets that can be used to borrow money; and (f) more positive experiences in managing land.

Benefits of the application of tenure reform scheme(s) for farmers' groups (mixed men and women, but dominated by men) or a particular women's group include: (a) ability to cooperate and exchange opinions with members; (b) ability to socialize and exchange experiences with other groups; (c) open discussion of problems; (d) cooperation in managing the land to increase the group's cash income; (e) help to get seeds and support to borrow from the bank; (f) collective income from processing nontimber forest products; (g) legal permit for managing land in state forest; and (h) increased spirit of mutual cooperation among members of the group(s).

Women and men of different communities in the research areas have developed different livelihood strategies after the implementation of forest tenure reform schemes (for the case of Lampung) and prior to the selection of suitable of forest tenure scheme (for the case of Maluku). These include landbased strategies such as planting trees that have high economic value, such as coffee and fruit trees, on forest lands. In Lampung, these forest lands are part of HKm or HTR schemes and are 'secured lands'. In Maluku, the forest lands managed collectively by women and men of local communities are considered part of customary forests (hutan adat) and customary areas (wilayah adat). Some parts of these forest lands, however, are seen by the state as state forest lands.

In addition to managing forest lands, local women in CIFOR's research sites in Lampung and Maluku have established home-based businesses, such as producing processed food from agricultural products, and managing food stalls and small shops selling goods for basic needs. In managing these livelihood strategies, women and men of different communities apply a gendered division of labor that is relatively flexible. Nevertheless, there are some families that still face economic problems due to crop failures, an absence of alternative livelihoods and too many dependents to feed. 


\section{Conclusion}

Gender dimensions and dynamics within forest tenure reform policies at global level (macro scale) are marked by the intersection of global efforts toward gender equality and women's empowerment and toward just and sustainable forest resources through forest tenure reform. In addition to CEDAW, Goal 5 of SDGs and the VGGTs serve as critical references for the development of just and equitable forest tenure reform policies and initiatives at the national and subnational levels.

National policies on gender equality and women's empowerment in Indonesia, which are part of the meso scale of the framework, have contributed to the development of gender mainstreaming policies within the forestry sector. Nevertheless, national forest tenure reform policies, programs and schemes are still very limited in the adoption of gender equality and women's empowerment. Government agencies that are part of the development and implementation of forest tenure reform have not adequately applied gender equality and women's empowerment perspectives to daily activities.

The meso scale of the gender dimension of forest tenure reform that applies at the provincial and district levels is marked by the implementation of gender-neutral national forest tenure reform policies and programs at landscape level. Lampung Province has two permits within the national social forestry scheme, HKm and HTR, while in Maluku Province hutan adat is commonly found.

At the micro scale, the case study of Lampung Province shows that the implementation of forest tenure reform schemes has not significantly changed gender norms. Women's participation in decision making at household and community level is gradually increasing, although it is limited. Gendered access to education at the micro scale has slowly increased after the implementation of forest tenure reform schemes in Lampung. This relates to the increasing of income from forest lands that have been secured. The implementation of forest tenure reform through the issuance of HKm and HTR permits has also made women feel safe and secure in managing the land, they no longer fear authorities, can manage non-timber forest products, can earn cash income that can be used to cover living expenses, and can preserve the plants from extinction by replanting them. It has also decreased men's temporary migration for work or additional cash income. The presence of more adult men in the family has positively contributed to the utilization of the forest lands under the HKm permit, which is gradually bringing positive impacts for forest lands and resources.

In Maluku Province, where the local communities are still searching for the best scheme to legally protect their tenure rights to forest lands and resources, the existing tradition of active participation of women in decision making at household and community levels could contribute to the recognition and protection of the rights of women and other marginal groups with respect to forest lands and resources. 


\section{References}

Bose P, Larson AM, Lastarria-Cornhiel S, Radel C, Schmink M, Schmook B, Vázquez-Garcia V. 2017. Women's rights to land and communal forest tenure: A way forward for research and policy agenda in Latin America. Women's Studies International Forum 65: 53-9.

Colfer CJP. 2013. The Gender Box: A framework for analyzing gender roles in forest management. Occasional Paper 82. CIFOR: Bogor, Indonesia.

[FAO] Food and Agriculture Organization. 2012. Voluntary Guidelines on the Responsible Governance of Tenure of Land, Fisheries and Forests in the Context of National Food Security. FAO: Rome.

[FAO] Food and Agriculture Organization. 2006. Understanding forest tenure in South and Southeast Asia. Forestry Policy and Institutions Working Paper No. 14. FAO: Rome.

Fortmann L. 1985. The tree tenure factor in agroforestry with particular reference to Africa. Agroforestry Systems 2:229-51.

Fortmann L and Bruce JW, eds. 1988 Whose Trees? Proprietary Dimensions of Forestry. Boulder, CO: Westview Press.

Herawati T, Liswanti N, Banjade MR and Mwangi E. 2017. Forest tenure reform implementation in Lampung Province: From scenarios to actions. CIFOR Infobrief No. 169. CIFOR: Bogor, Indonesia.

[KOMNASHAM] Komisi Nasional Hak Asasi Manusia. 2016. Inkuiri Nasional Komisi Nasional Hak Asasi Manusia: Hak Masyarakat Hukum Adat Atas Wilayahnya di Kawasan Hutan. (The National Commission on the Human Rights. 2016. National Inquiry on the rights of Indigenous Peoples over customary territories located in the forest zone). Jakarta, Indonesia: KOMNASHAM

Larson AM. 2012. Tenure Rights and Access to Forests: A Training Manual for Research. Bogor, Indonesia: CIFOR.

Liswanti N, Tjoa M, Silaya T, Banjade MR and Mwangi E. 2017. Securing tenure rights in Maluku: searching for common actions. CIFOR Infobrief No. 170. CIFOR: Bogor, Indonesia.

Maine H. (1861) 2015. Ancient Law. Cosimo Classics: New York.

Maine H. (1871) 2007. Village Communities in the East and West. Read Books: Vancouver.

Ostrom E. 1990. Governing the Commons: The Evolution of Institutions for Collective Action. Cambridge: Cambridge University Press.

Ostrom E. 1999. Private and common property rights. In Bouckaert B and De Geest G, eds. Encyclopedia of Law and Economics. Cheltenham, UK: Edward Elgar. 332-79.

Marcoes L, Rachman NF, Sirimorok N and Toumbourou. 2015. Achieving Gender Justice in Indonesia's Forest and Land Governance Sector: How Civil Society Organizations Can Respond to Mining and Plantation Industry Impacts. Jakarta: The Asia Foundation.

Rachman NF and Siscawati M. 2016. Forestry law, masyarakat adat, and struggles for inclusive citizenship in Indonesia. In Antons C, ed. Routledge Handbook of Asian Law. London: Routledge. 224-29.

Rachman NF and Siscawati M. 2014. Masyarakat Hukum Adat adalah Penyandang Hak, Subyek Hukum, dan Pemilik Wilayah Adatnya: Memahami secara Kontekstual Putusan Mahkamah Konstitusi Republik Indonesia atas Perkara Nomor 35/PUU-X/2012 [Indigenous Peoples are The Rights Bearer, Legal Subject, and the Owner of Customary Territories: Understanding the Context of the Constitutional Court Ruling of the Case No. 35/PUU-X/2012]. Yogyakarta, Indonesia: Insist Press.

[RRI] Rights and Resources Initiative. 2017. Power and Potential: A Comparative Analysis of National Laws and Regulations Concerning Women's Rights to Community Forests. Washington DC: Rights and Resources Initiative.

Siscawati M. 2014. Pertarungan Penguasaan Hutan dan Posisi Perempuan Adat [Struggles of Forest Control and the Position of Indigenous Women]. Jurnal Wacana No. 33 Tahun XVI. 
Siscawati M, Banjade MR, Liswanti N, Herawati T, Mwangi E, Wulandari C, Tjoa M and Silaya T. 2017. Overview of Forest Tenure Reforms in Indonesia. CIFOR Working Paper No. 223. CIFOR: Bogor, Indonesia.

Siscawati M and Mahaningtyas A. 2012. Gender justice: Forest tenure and forest governance in Indonesia. In Buchy M, Giri K, Jamisolamin J, Mahaningtyas A, Gurung J, Setyowati AB, Wang X, Basik N, Chapagain A, Ndjebet C, eds. The Challenges of Securing Women's Tenure and Leadership for Forest Management: The Asian Experience. Washington, DC: Rights and Resources Initiative.

von Benda-Beckmann F, von Benda-Beckmann K and Wiber M. 2006. Changing Properties of Property. New York and London: Berghahn Books. 



\section{DOI: $10.17528 /$ cifor $/ 007572$}

CIFOR Working Papers contain preliminary or advance research results on tropical forest issues that need to be published in a timely manner to inform and promote discussion. This content has been internally reviewed and has undergone limited external peer review.

This Working Paper analyzes the gender dimensions of forest tenure and forest tenure reform in Indonesia. Data were derived from CIFOR's research on forest tenure reform at the national and provincial levels, focusing on the provinces of Lampung and Maluku. Additional data were taken from training workshops on gender and community-based forest tenure reform held at these two sites. The study forms part of CIFOR's Global Comparative Study on Forest Tenure Reform (https://www.cifor.org/gcs-tenure/).

\begin{tabular}{|c|c|c|}
\hline CGIAR & $\begin{array}{l}\text { RESEARCH } \\
\text { PROGRAM on } \\
\text { Policies, } \\
\text { Institutions, } \\
\text { and Markets }\end{array}$ & $\begin{array}{l}\text { The CGIAR Research Program on Policies, Institutions, and Markets (PIM) leads action-oriented } \\
\text { research to equip decisionmakers with the evidence required to develop food and agricultural policies } \\
\text { that better serve the interests of poor producers and consumers, both men and women. PIM combines } \\
\text { the resources of CGIAR centers and numerous international, regional, and national partners. The } \\
\text { program is led by the International Food Policy Research Institute (IFPRI). www.pim.cgiar.org }\end{array}$ \\
\hline & Led by IFPRI & \\
\hline
\end{tabular}

\begin{tabular}{|l|l|l|l} 
This research was carried out by CIFOR as part of the CGIAR Research Program on Forests, \\
Trees and Agroforestry (FTA). FTA is the world's largest research for development program \\
to enhance the role of forests, trees and agroforestry in sustainable development and food \\
security and to address climate change. CIFOR leads FTA in partnership with Bioversity \\
International, CATIE, CIRAD, INBAR, ICRAF and TBI.
\end{tabular}

cifor.org | forestsnews.cifor.org

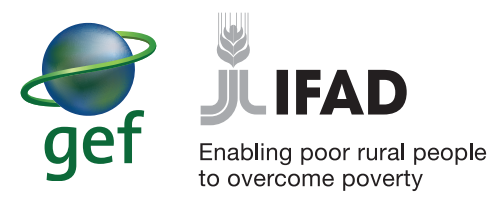

Food and Agriculture Organization of the United Nations
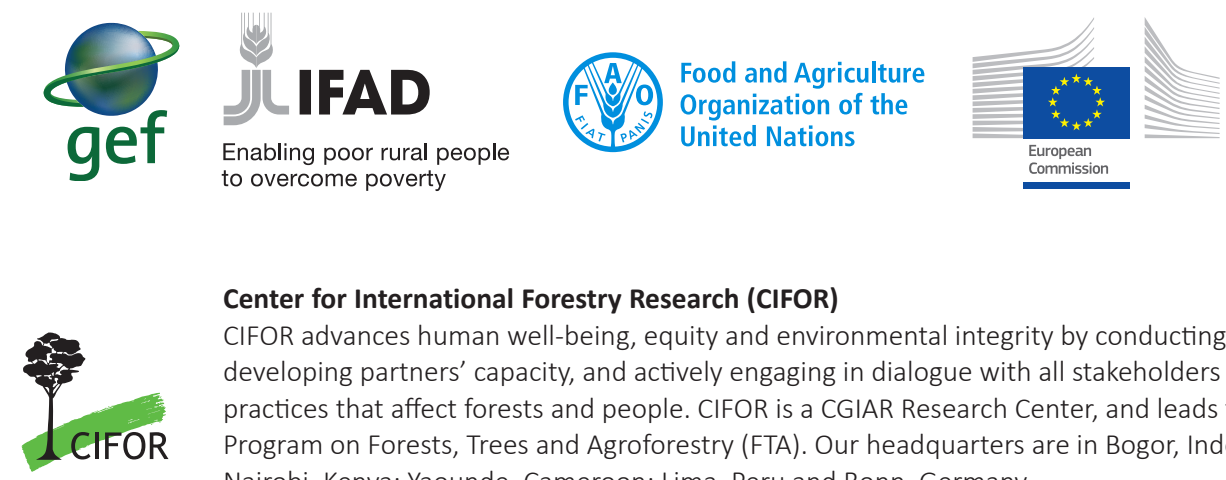

Center for International Forestry Research (CIFOR)

CIFOR advances human well-being, equity and environmental integrity by conducting innovative research, developing partners' capacity, and actively engaging in dialogue with all stakeholders to inform policies and practices that affect forests and people. CIFOR is a CGIAR Research Center, and leads the CGIAR Research Program on Forests, Trees and Agroforestry (FTA). Our headquarters are in Bogor, Indonesia, with offices in Nairobi, Kenya; Yaounde, Cameroon; Lima, Peru and Bonn, Germany.

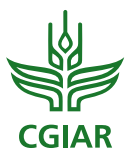

